\title{
THE DEPICTION OF THE IMAGE OF A CREATIVE PERSON IN AUTOBIOGRAPHICAL INSCRIPTIONS
}

\author{
Normuhammad Xasanovich Ubaydullayev
}

Teacher, Samarkand Branch Of The Center For Training (BCT) And Professional Development Of The Basics Of Working In The State Language (PDBWSL) Under The Tashkent State University Of Uzbek Language And Literature Named After Alisher Navoi, Uzbekistan

\section{ABSTRACT}

The history, origin and development of memoirs and autobiographical works in Uzbek literature go back a long way. This genre has always brought clarity to problematic situations. Autobiographical works are also relevant in modern literature and meet all the requirements of the rules of literature. Researchers have studied the peculiarities of autobiographical works. Although memoirs are essentially close to biographical works, they differ slightly, depending on the nature of the genre. In ancient times, scholars wrote on manuscripts, stone inscriptions, and pottery in order to pass on information about their life and work from generation to generation. That's why a lot of information has come down to us through their work.

KEYWORDS: - Autobiographical work, realistic work, creative, personal image, memoir, memory, biographical work, textbook, problem-based learning, contemporary thought.

\section{INTRODUCTION}

Literary scholar Bakhodir Karimov in his scientific monograph "Abdulla Kadiri and hermeneutic thinking" under the heading "Artwork and biographical information" describes the state of creative biography as follows: "It is difficult to separate the biographies of writers and poets, and artists in general, from their works, and at the same time from the biographies of their works. Indeed, there is a biographical method in world literature that exaggerates this aspect of the problem and brings it into a systemic state. However, the artistic interpretation of events reflects the artist's spiritual experiences, life experiences, which no one can deny. The author's biography is somehow reflected in his works. And to some extent it ensures the originality of the work of art. The interpretation of a work of art against the background of changes in the life of the writer, emotional experiences, shocks in his worldview, of course, has a positive effect [1, pp. 183-184]".

\section{T HE MAIN FINDINGS AND RESULTS}

In the textbook "Literature" published for the 5th grade of general secondary schools in 2015 [2, P.133-141], the story of Abdulla Kadiri "Uloqda" was referred to the judgment of the students. In the textbook "Literature" published in 2020 [3, pp. 93-109], this work, which glorifies our national values and tells the story of the immaculate memories of childhood, was removed. We don't know why. True, a student living in a multi-stored building may not imagine 
CURRENT RESEARCH JOURNAL OF PHILOLOGICAL SCIENCES 2(7): 36-39,

May 2021 DOI: https://doi.org/10.37547/philological-crjps-02-07-09

ISSN 2767-3758

(C)2021 Master Journals

\section{Crossref do) 8 Google}

Accepted26 thJuly, 2021 \& Published 31 thJuly, 2021

the story of "Uloqda", but the presentation of works about the traditions, values, and national traditions inherited from our ancestors through visual aids, videos. If we try to do it, the child will have a clear idea. This method serves to increase the quality and effectiveness of the lesson. We think it was good that this story was included in the textbook.

Why are we talking about this? Because Abdulla Kadiri's story "Uloqda" plays an important role in the study of his life. The scenes in the story are not fabric, but about what he knew and saw about the people in the neighborhood where he grew up. It is important that the writer's childhood memories are recorded. Habibullah Kadiri writes that in 1936, when his father was preparing to republish the story "Uloqda", under the heading "This story was written in 1915. I didn't make any changes because it was a reminder of my childhood [4, B19]". It is clear that the writer did not exaggerate what he saw, but acted on the basis of clear, realistic facts. The characters are also people he knows.

Sabir Mirvaliyev, one of the hard-working and active literary scholars, wrote in his book "Uzbek Literature" about Abdulla Kadiri, one of the great figures of Uzbek literature, and his biography, clarifying the life of the writer until 1926:

"In any case, I was born into a poor family, living in a garden. When I was nine or ten, I was sent to school. I went to school the old-fashioned way for about two or three years, and when I was twelve years old, I was hired by a rich man because my family was living in extreme poverty. My master was a merchant and needed someone who could write in Russian. It must have been that he sent me to a Russian school. In 1912, I became a clerk for 50 rupees a year for a man who traded in manufactories. In the meantime, I read the newspapers published by the Tatars on the market and believed that there was a newspaper in the world. In 1913, when the
Uzbek newspapers "Sadoi Turkiston", "Samarkand", and "Oina" began to appear, the thought of writing a speech awoke. I didn't even notice that I wrote a theater book called "The Unhappy Groom" under the influence of "Padarkush", published in 1913 [5, pp. 27-28].

When school textbooks are based on the biographies of our poets and writers, or on the stories told by their children and contemporaries, the student's interest and confidence increase. His love and affection for writers will increase. As the reader reads the author's work, he tries to embody the character of the writer in the character of the protagonist. He believes that all the positive qualities belong to them.

Well-known German scholar Ingeborg Baldauf in his scientific and journalistic pamphlet "Drawings on the Uzbek literature of the XX century" expresses his views, observations and opinions about Abdulla Kadiri as follows: "Since Abdulla Kadiri himself called the events in the book "natural", it means that they are very realistic, that is, in any case, "the first realistic" $[6$, p.55]".

Scholar Ingeborg Baldauf had a soul in his thoughts. After all, almost all the works of the writer are based on real reality. The protagonists are also people of that time. The writer observes and studies the character of the people around him. They become, at least in part, episodic.

Commenting on the "caution and falsity in the translation of the case", the literary critic A. Rasulov emphasizes the importance of the organic connection between the biography of the writer and his work, the spiritual closeness: "There is an inextricable link between a writer's status and his work. Every play reflects the spirit, mood and heart of the writer. If the works are carefully studied, they tell a lot about the writer's condition and psyche [7, p. 27]". 
CURRENT RESEARCH JOURNAL OF PHILOLOGICAL SCIENCES 2(7): 36-39,

May 2021 DOI: https://doi.org/10.37547/philological-crjps-02-07-09

ISSN 2767-3758

(C)2021 Master Journals

\section{Crossref do) 8 Google}

Accepted26 th July, 2021 \& Published 31 ${ }^{\text {th }} J u l y, 2021$

In fact, in all of his works, the truth of life is reflected. This is confirmed by his son Habibullah Kadiri. In his book On My Father, the author's son makes convincing assumptions about prototypes. The author's contemporary Usmonboy's unique outlook describes his appearance as follows: "Osmanboy's behavior, dress, speech, and appearance, though partial, seem to be reflected in the image of Yusufbek Khaji ..." he wrote. Yusufbek compares some aspects of Haji's image to another person. This author assumes that Abdulla Kadiri's acquaintance in Eshanguzar mahalla was a "teacher named Mullah Alijon" [4, p. 113].

Literary critic Abdugafur Rasulov, in his book "Fiction - Innocent News", evaluates the work of Abdulla Kadiri: "Abdulla Kadiri is a leading artist of new literature. Its heyday coincided with the years of the October Revolution. To me, The Story of the "Uloqda" was the good news about the birth of a great artist. In both novels, Abdulla Kadiri describes "the dirtiest period in the history of our people". In other words, the novels portrayed a socio-political darkness. The decoration of the dark night is the bright stars of joy.

Abdulla Kadiri was a master of creating artistic character. This art of the writer is distinguished by his ability to convincingly portray the images of living people. At present, the issue of the hero of Uzbek Soviet literature remains unresolved. For more than seventy years, Uzbek Soviet literature has allowed artificiality in the creation of a heroic character [8, p.154-155].

The story of the "Uloqda" is good news about the birth of the great writer, says the scientist. The simple, fluent language of the work captivates the reader. The course of events is also characterized by vitality, reliable creation of images and characters. Abdulla Kadiri avoided artificiality in creating the inner world of his heroes and preferred naturalness. With this, the reader won his heart.

When talking about Abdulla Kadiri's life in literature textbooks, it is advisable to use his autobiography, which he first wrote, as well as his son Habibullo Kadiri's biographical memoir "About my father" and his works of art.

In one place he writes: "The years of Kadiri's birth, as mentioned above, will be a time of great economic hardship in the family of Kadiri Baba. Grandfather Kadiri was very weak at the time, he was over seventy years old, he had no permanent income, his eldest son Rahimberdi was now fifteen years old, he could not do anything, the garden His income was not enough to live on for five years (in 1897, his younger brother Kudratullah was born). My father wrote about these times:

"I didn't know if I was born into a rich family or a poor family. But when I was 7-8 years old, I knew for sure that my stomach was not full of soup that the food of five souls came only from the labor of my 80-year-old father, from the summer harvest of 1,300 sarjin. If spring comes badly and the orchards are exposed to the sun, we will also face hunger and winter [4, p. 6].

The student feels the atmosphere of that period from the inside. Despite the famine, Saadi's books such as "Gulistan", "Rustami doston", "Hotamtoy", "Mashrab", "Navoi", "Kalila and Dimna" It's amazing what he did. Compared to the modern child, there is a difference between heaven and earth. Despite all the conditions (full stomach, idol), there are still some lazy students. There are many young people who are inspired by the author's biography and strive to be like him.

Let's turn to the biographical work "About my father":

“My uncle Rahimberdi's wife, Robi, said:

- Mulla Abdulla has been a serf since childhood. When he was unjustly offended, he could not 
CURRENT RESEARCH JOURNAL OF PHILOLOGICAL SCIENCES 2(7): 36-39,

May 2021 DOI: https://doi.org/10.37547/philological-crjps-02-07-09

ISSN 2767-3758

(C)2021 Master Journals

Crossref dof 81 Google

Accepted26 th July, 2021 \& Published 31 ${ }^{\text {th }} J u l y, 2021$

bear to look at her with shock, and shed tears [4, p. 7]".

It is clear that Abdulla Kadiri was a child who could not stand injustice in his youth. Despite his young age, we can see from his memory that he was an independent, clear-minded, thoughtful young man.

It would be a great light upon light if the school's literature textbooks focused on the above aspects of teaching Abdulla Kadiri's life and work. The teacher should ask students what they know and have heard about the artist before covering a new topic. This is because it is important that the teacher does not repeat what the students have learned and that the lesson schedule is used effectively.

\section{Conclusion}

To conclude, it would be good if students could be given a detailed account of the writers' lives by teachers during the lesson. As the reader reads the author's works, he travels imaginatively to the places he travels, meets people of different destinies, and witnesses both sad and happy events.

\section{ReFERENCES}

1. Karimov B. (2014) Abdulla Kodir's and hermeneutic thinking: scientific monograph. - Tashkent: “Akademnashr". - pp. 183-184. (Karimov B. Abdulla Qodiriy va germenevtik tafakkur: ilmiy monografiya.-T.: Akademnashr, 2014-y.183-184-betlar.)

2. Ahmedov S., Kasimov B., Kochkarov R., Rizayev Sh. (2015) Literature (5th grade textbook, part I). - Tashkent: Sharq Publishing and Printing Joint-Stock Company. - pp. 133-141. (Ahmedov S.,Qosimov B., Qo'chqorov R., Rizayev Sh. Adabiyot(5-sinf darsligi I qism).-T.: «Sharq» nashriyot-matbaa aksiyadorlik kompaniyasi
Bosh tahririyati, 2015-y., 133-141-betlar.)

3. Ahmedov S., Kasimov B., Kochkarov R., Rizayev Sh. (2020) Literature (5th grade textbook). - Tashkent: Sharq Publishing and Printing Joint-Stock Company General Editorial Board. - pp. 93-106. (Ahmedov S.,Qosimov B., Qo'chqorov R.,Rizayev Sh.Adabiyot(5-sinf darsligi). -T.: «Sharq» nashriyot-matbaa aksiyadorlik komponiyasi Bosh tahririyati, 2020-y., 93-106-betlar.)

4. Kadiri H. (1983) About my father. Tashkent: Ghafur Ghulam Publishing House of Literature and Art. - p. 9. (Qodiriy H. Otam haqida. - T.:G'afur G'ulom nomidagi Adabiyot va san'at nashriyoti, 1983-y., 19bet.)

5. Mirvaliyev S. (2000) Uzbek writers. Tashkent: "Writer". - pp. 27-28. (Mirvaliyev S.0'zbek adiblari.-T.: Yozuvchi, 2000-y., 2728-betlar.)

6. Ingeborg Baldauf. (2001) Drawings on 20th century Uzbek literature. - Tashkent: "Manaviyat". - p. 55. (Ingeborg Baldauf. XX asr o'zbek adabiyotiga chizgilar.-T.: Ma'naviyat, 2001-y., 55-bet.)

7. Rasulov A. (1998) Science longs for the stranger. - Tashkent: "Manaviyat". - p. 27. (Rasulov A. Ilmi g'aribani qo'msab...-T.: Ma'naviyat, 1998-y., 27-bet.)

8. Rasulov Abdugafur. (2007) Art is a novelty.. - Tashkent: Sharq Publishing and Printing Joint-Stock Company General Editorial Office. - pp. 154-155. (Rasulov Abdug'afur.Baddiylik-bezavol yangilik.-T.: «Sharq» nashriyot-matbaa aksiyadorlik komponiyasi Bosh tahririyati, 2007-y., 154155-betlar.) 